\title{
Social legitimacy and political authority: the case of international organizations
}

\author{
Ander GUTIÉRREZ-SOLANA JOURNOUD *
}

\begin{abstract}
The article analyses the consolidation of the political authority of international organizations in terms of their social legitimacy. Since international organizations lack coercive means to assert their authority, they depend on favourable external perceptions of their functioning, which is why the social legitimacy of international organizations is one of their principal sources of power. As such, international organizations are conceived of as global political communities in which states and global civil society, on one hand, share the principles, values and objectives of this community, and, on the other hand, are convinced of their ability, through social and discursive action, to modify common perceptions of reality. This way, social legitimacy is the non-material capacity of international organizations to ensure compliance, based on the subjective perceptions of the states and civil society of three dimensions with respect to the behaviour of international organizations: moral values, the principal of legality and effectiveness. The perceptions these legitimising actors, which construct the social legitimacy of an international organization, can be studied, the article argues, through the analysis of their discourses.
\end{abstract}

Keywords: International Organizations - legitimacy - authority - political community - global civil society

\section{(A) INTRODUCTION}

One of the fundamental tasks of International Relations as a discipline is to discern the influence and role of the various actors of international society. At present, different forces, both public and private, are competing for international influence. Also, the internal and foreign policies of states are increasingly conditioned by dynamics outside of state control. As such, there is a widening gap between the idea of a traditional state-centered political community and the dynamics inherent in the globalised world ${ }^{2}$. In this context of the progressive loss of state influence ${ }^{3}$ it is pertinent to ask what happens to the role of the other public actors of international society, namely the international organizations (International Governmental Organizations (IGOs)), with respect to the configuration of their political authority and, in consequence, how their images as legitimate are created.

There is not one common and shared definition of international organizations. In a legal perspective international organizations are "voluntary associations of States established by international agreement, endowed with permanent and independent bodies responsible for managing collective interests capable of expressing a will legally different from that of its members"4. In a more

\footnotetext{
Assistant Professor of Public International Law, University of Basque Country (UPV/EHU). Email: ander.gutierrez-solana@ehu.eus.

I W. Sandholtz, and M.M. Gray, "International Integration and National Corruption", 57(4) International Organization, (2003) 76I-800, at 764 [doi: I0.I0I7/S00208I8303574045]

2 D. Held, La democracia y el orden global. Del Estado moderno al gobierno cosmopolita, (Paidós, Barcelona, I997), at I66. For a further research about cosmopolitism see also, C. Garcia Segura et. al., La Tension Cosmopolita. Avances y límites en la institucionalización del cosmopolitismo (Tecnos, Madrid, 2016).

3 See: T. M. Fazal, "State death in the International System", 58(2) International Organization $20043 \mathrm{II}-344$ [doi: I0.I017/So020818304582048]; S. Strange, La retirada del Estado (Icaria, Barcelona, 200I), at 23.

4 J.M. Sobrino Heredia, "Las Organizaciones Internacionales. Generalidades", in M. Diez de Velasco (ed) Las Organizaciones Internacionales (Tecnos, Madrid, 2006) 44, at 37-55.
} 
sociological perspective, international organizations are also seen as instruments, arenas and, obviously, as actors ${ }^{5}$

This article proposes a notion of social legitimacy ${ }^{6}$ applicable to international organizations, taking into account the specific characteristics of these, both legal and sociological. For that, IGOs entourage is observed as global political community in which states and global civil society, namely legitimising actors, examine the degree of their common principles, values and objectives with the organizations. States and global civil society are both part of the global community. Being convinced of their ability, through social and discursive action, to modify common perceptions of reality, their discursive practice about the IGOs behaviour generates the social perception of legitimacy. The dimension of IGOs reality which legitimising actors examines is called in this article the three objective dimensions and reflects the whole behaviour of the IGO.

Until now, the various studies of the legitimacy of international institutions have focused on the justification for their capacity of elaborating norms, based on a strict adherence to foreseen procedures $^{7}$. One strand has focused on effectiveness and accountability ${ }^{8}$ whereas another has consisted in general reflections over the challenge posed by the lack of convergence between the values of the IGO and the policies pursued 9 which leads to low expectations on behalf of states and citizens ${ }^{\mathrm{I}}$. These reflections, although fundamental for comprehending the institutional reality of IGOs, do not offer a concrete and useful concept that allows for understanding what legitimacy means to an IGO, how legitimacy is created and which methods should be used, by researchers and the IGOs themselves, to evaluate the level of legitimacy and identify the strong and weak points of international institutions in this respect.

The notion of social legitimacy presented here is based on constructivist ideas and brings forth a framework for studying the processes through which the IGO's images of legitimacy are created and consolidated, including the identification of the strengths and weaknesses of these images. International organizations are institutions with a political and legal decision-making capacity which

\footnotetext{
5 V. Rittberger and B. Zangl, International Organization. Polity, Politics and Policies (Palgrave MacMillan, New York, 2006), at 6-8.

6 The notion presented in this article is the result of several empirical studies made about different IGOs (some of them published in A. Gutiérrez-Solana, La legitimidad social de las Organizaciones internacionales. Estudio de las percepciones estatales $y$ de la sociedad civil de la ONU, OMC $y$ OIT (Madrid, Tecnos, 20I4)). The conclusions emerged from those studies are in the core of the theoretical notion presented here.

7 See: T. Franck, The power of legitimacy among nations (Nueva York, Oxford University Press, 1990); D. Esty, "Good governance at the supranational scale: globalizing administrative law", II5(7) Yale Law Journal 2006, I490-1563 [doi: I0.2307/20455663], D. Zaum, "The authority of international administrations in international society", 32 (3) Review of International Studies (2006) 455-473, at. 457 [doi: I0.1017/S0260210506007iIX].

8 See: R.O Keohane and J. S. Nye, "The Club Model of multilateral cooperation and the WTO. Problems of democratic legitimacy", 4 Visions of governance in the 2Ist century, Working Paper Series (200I); A. Buchanan, and R.O Keohane, "The legitimacy of global governance institutions", 20 (4) Ethics and International Affairs (2006) 405-437, at 409 [doi: I0.Im/j.1747-7093.2006.00043.x]; R.O., Keohane, "Accountability in world politics", 29 (2) Scandinavian Political Studies (2006) 75-87, at. 86 [doi: I0.In/j.I467-9477.2006.00I43.x].

9 J.M. Coicaud, y V. Heiskanen, The legitimacy of International Organizations (New York, United Nations University Press, 200I).

Io J.M Coicaud, "Legitimacy across borders and over time" in H. Charlesworth y J.M. Coicaud (eds) Fault lines of international legitimacy (New York, Cambridge University Press, 2010) at 2I.
} 
exists in an international society, which, although difficult to pin down, is by no means anarchic cause the existence of legitimates IGO implies the existence of some power over the states ${ }^{\text {II }}$. Their authority depends largely on the image provide by legitimising actors in their interaction

This social notion of legitimacy implies, as will be argued, that the social legitimacy of IGOs is consolidated when states and global civil society, members of a single political community, engage in a subjective evaluation of the objective dimensions that bind together this very community, in dialectic and mutually understood process.

This way, the article sets out by linking the ideas of legitimacy and political authority. Next, it conceptualises the social environment that surrounds an international organization as a global political community, where the actors that constitute it share values and objectives and mutually recognise each other as subjects of the community ${ }^{\mathrm{r} 2}$. Third, it analysis the roles played by legitimising actors, states and global civil society, in the construction of the legitimacy of IGOs, as well as the different objective dimension that are taken into account in the construction. These criteria, which are expressed in public by the legitimising actors are: the values of the international organization, whether the behaviour of the international organization follows the principle of legality and, finally, the effectiveness of the actions of the international organization.

To have a framework of analysis of these characteristics is fundamental for strengthening the role that international organizations should play in the near future, when private actors occupy central positions and there is no public institution to exercise control over these. To know the degree of social legitimacy of an organization allows for uncovering the problems (if there are any), identifying which actor observes delegitimizing behaviour in the organization and thus proposing solutions to the problems.

\section{(B) WHICH CONCEPT OF LEGITIMACY?}

\section{(I) Social Legitimacy for an unforced authority}

The study of the role played by international organizations implies a revision of their capacity to act and the authority with which fulfil their functions, given that international organizations are in these days the principal source of the creation of international law ${ }^{13}$. Furthermore, the activities of international organizations have the function of raising awareness and mark minimum standards for acceptable international behaviour. In this sense, it is crucial to say that the debate about the European Union's legitimacy ${ }^{14}$ is considered here as an issue of social representation and not a real

\footnotetext{
II I. Hurd, "Legitimacy and Authority in International Politics", 53 (02) International Organization 1999, at 399; [doi: I0.1162/002081899550913]

I2 R.A. Payne and N.H. Samhat, Democratizing global politics (Albany, State University of New York Press, 2004) at 39.

I3 C.C. Joyner, International Law in the 2Ist Century (Oxford, Rowman and Littlefield Publishers, 2005), at 86.

${ }^{14}$ For a current review about this debate see: V.A Schmidt, "Democracy and Legitimacy in the European Union Revisited: Input, Output and "Throughput” 6r:I Political Studies (2013) at 2-22 "doi: https://doi.org/I0.mm/j.I4679248.2012.00962.x]
} 
legitimacy debate ${ }^{15}$. Nevertheless, when we link the concepts of legitimacy and authority it is necessary to consider in depth in meaning of both terms since, apart from the capacity to establish norms, the authority of an organization is reflected in the concept of legitimacy. Public authorities need a specific area of competences within which to function as norm creators, but this is not sufficient for the norms and rules created to have a direct effect upon the receivers. To be effective, a political authority needs the receiving subjects to recognise it as an authority, and this recognition is what is known as legitimacy. This way, the concept of legitimacy, originally used to configure the legal authority of the state to create norms and enforce compliance, refers a quality of the public power which recognises it as an authority. This recognition implies a predisposition to abide by the norms of the institution in question and is in itself a reflection of how the norms are perceived ${ }^{16}$. The predisposition to abide by the norms is founded in a belief that the norm should be obeyed because, the norm itself or the institution that approved it, has a special quality beyond the capacity of impose the compliancer7. In this sense, the predisposition is linked with the belief not with the fear to be enforced to abide.

The idea of social legitimacy does not refer to similar concepts such as justice, procedure or, of course, the interest that an actor may have in an international organization. Legitimacy is to be understood as an idea or perception that, although it has with different consequences depending on the analyst, bestows the ultimate justification on the establishment of an authority. Social legitimacy goes beyond the weberian sources of legitimacy but keep their link between legitimacy and authority to build a legitimate order ${ }^{\text {r8 }}$. Legitimacy is a characteristic of hierarchical and not authoritarian social relations, and in consequence it is important to comprehend the dynamics of a society in order to estimate the degree of legitimacy that an authority has within it.

Legitimacy is not a static commodity, but depends on the actor that judges whether an organization is legitimacy. Objectivist affirmations of legitimacy are therefore absurd. The construction of social legitimacy takes place through the interaction of the authority and its subject in a dialectic process, where previously defined objective dimensions are given meaning. From this process of signalling, interpretation and responding emerges the "intersubjetive significance" other actor, which in turn are elements in the construction of the identity, interests and external image of each actor.

The idea of legitimacy determines if a power is considered conventional or authoritarian and, as a function hereof, an actor develops the relation with the institution ${ }^{20}$. In effect, the idea of legitimacy

\footnotetext{
Is The difference made between European Union and other international organizations arises from the definition of EU as an international organization of integration. In this sense, the only real example of this kind of IGOs is the European Union (see Sobrino Heredia, supra n. 4, at 52-53).

16 KJ. Pelc, "Constraining Coertion? Legitimacy and its Role in U.S Trade Policy, 1975-2000", 64 (oI) International Organization (2010) 65-96, [doi: 10.1017/S0020818309990245].

I7 Hurd, supra n. II, at 38I; I. Miyaoka, Legitimacy in International Society. Japan's reaction to global wildlife preservation (New York, Palgrave McMillan, 2004), at II.

i8 M. Weber, Economía y Sociedad: Esbozo de sociología comprensiva, (México, Fondo de Cultura Económica, 1979).

is A. Wendt, "La anarquía es lo que los Estados hacen de ella. La construcción social de la política de poder", i Revista Académica de Relaciones Internacionales (2005), at 15.

20 I. Hurd, After anarchy (Princeton, Princeton University Press, 2007), at 2-II.
} 
refers to the sentiment of having a commitment to the political entity in question ${ }^{21}$. This recognition of the capacity of create binding norms by an institution is their authority ${ }^{22}$ and is created by the consolidation of social legitimacy.

This idea of social legitimacy cannot be shown only by investigating the concrete material reality but must, on the point of departure in basic ideas about the "sociology of knowledge"23 analyse the perceptions impressions that explain and justify the behaviour of the actors who receive the norms. The point of departure is thus in the constructivist assumption that the structures that regulate the international reality are social rather than material in nature ${ }^{24}$. Legitimacy implies the social recognition of the authority of an actor to emit norms ${ }^{25}$. In consequence, an organization that is not socially legitimised can only have power, but not authority.

\section{(2) Social Legitimacy depends on external image, not self-identity}

The legitimacy of an organization forms part of the construction of its identity, sums up what it means to other actors, what role it plays and what role it is expected to play. But image and identity should not be confused. Decoupling legitimacy from the concept of selfe is going further than the identity debates after Wendt and, the construction of a public image such as legitimacy, does not depend on the actors own opinion of itself, but on the external perceptions only. This can reflect why often IGOs see themselves in a more positive light that do the legitimising actors.

The process creating the legitimate image of an organization is based in a dynamic of mutual recognition, which permits a shared idea, concept, law etc. to work $\mathrm{k}^{27}$. This recognition forms part of the identity of the legitimised organization as well as of the legitimising actors. In fact, even though these actors bestow legitimacy upon the IGOs, it is these organizations that "establish, articulate and transmit norms" ${ }^{28}$ that define socially acceptable state behaviour, and impact on both the international behaviour and the external identity of the states.

International actor's behaviour has its causes and its reasons to acting ${ }^{29}$. In this sense, legitimacy does not cause behaviour but is a reason for behaving in a certain fashion. Social legitimacy, in this sense, is a key concept for the construction, built in the external and social relations between legitimising actors and IGO, of the feeling of commitment to an authority, a feeling which, nevertheless, does not entails posterior obedience. Social legitimacy, as a subjective quality is

\footnotetext{
21 Miyaoka, supra n. I7, at 7-23.

${ }_{22}$ B. Cronin and I. Hurd (eds), The UN Security Council and the politics of International Authority (Oxon, Routledge, 2008).

23 L.P Berger and T. Luckman, The social construction of reality (New York, Random House, 1967), at 19.

24 B. Frederking, The United States and the Security Council (Oxon, Routledge, 2007), at 5.

25 Cronin y Hurd, (eds), supra n. 22.

26 C. Epstein, "Who speaks? Discourse, the subject and the study of identity in international politics", $\mathrm{I} 7(2)$ European Journal of International Relations (201I) 327-350, [doi: 10.I177/1354066109350055]

27 J.G. Ruggie, Constructing the world polity. Essays on international institutionalization (New York, Routledge, 1998), at 22.

28 E. Adler, "Seizing the Middle Ground. Constructivism in World Politics", 3(3) European Journal of International Relations (1997) 319-363, at 345 [doi: 10.1177/1354066197003003003].

29 Ruggie, supra n. 27.
} 
constructed on the basis of shared values that do not automatically lead to compliance ${ }^{30}$. Nevertheless, the legitimacy of the organization emitting the norms does influence positively the inclination to comply without coercion or pressure ${ }^{34}$.

The notion of legitimacy reflects the relationship between actors. It not only influences the identity of the legitimised actor, but also structures the expected behaviour of the legitimising actors ${ }^{32}$. Social legitimacy reflects the conviction that fundamental values and internal norms of the organizations are shared and that the relationship is useful for both. In this sense, social legitimacy is constructed based on the link between the objective dimensions, which they are more or less stables, and the deliberation of a legitimising social sphere (the action of legitimising actors) who will solve the question about the organization's legitimacy in regarding his own criteria33.

(3) Social Legitimacy: a key for compliance

\section{(a) Social Legitimacy Brings Voluntary Compliance}

The approach adopted in this article implies recognising international relations as a social and political medium where actors are the subjects of a relation. This way, international organizations are considered "public spheres" of debate and participation. They are agents that create norms, but compliance with these norms does not depend so much on enforcing them as on the process by which they are created ${ }^{34}$.

In this perspective, an international organization offers processes of dialogue through which shared norms, rules and principles are created with the aim of managing the governance of a specific area of global politics. The viability of this governance depends on the ability and willingness of states and NGO's to work together towards a common objective ${ }^{35}$. The legitimacy of an international organization ultimately depends on the consent of the actors that must abide by the norms and rules created, as well as on the degree to which fundamental values are shared and on the perception of these actors of the procedures of the organization ${ }^{36}$.

The aforementioned point of view of international organizations goes beyond that Krasner's notion of regimes ${ }^{37}$. The approach to studying the legitimacy of international organizations needs to be more ambitions than the concept of international regimes permits. It is necessary to decouple the study of the legitimacy of international organizations from the national perspective that the regime concept entails and consider legitimate supranational governance as a separate, although related,

\footnotetext{
30 Hurd, supra n. II

3i C. Reus-Smit, "International Crises of Legitimacy", 44 International Politics (2007) 157-I74, at I70 [doi: I0.I057/palgrave.ip.8800I82].

32 I. Clark, Legitimacy in International Society (Oxford, Oxford University Press, 2005), at 23-24.

33 Reus-Smith, supra n. 3 I.

34 Payne and Samhat, supra n. I2, at 39.

35 Ibid. at 40.

36 J.M. Coicaud, Légitimité et politique. Contribution a l'étude du droit et de la responsabilité politiques (Paris, DUF, I997), at I3.

37 S. D. Krasner, "Structural Causes and Regime Consequences: Regimes as Intervening Variables", in S. D. Krasner (ed), International Regimes (Ithaca, Cornell University Press, I983), at I-2I.
} 
sphere. For supranational governance to be legitimate it must contain a collective decision-making process that includes the receptors of the norms generated, is capable of controlling abuses of power control legitimacy - and that produces effective solutions-output legitimacy ${ }^{3}$. This way, the ability of the legitimising actors to estimate the legitimacy of an organization therefore depends on the development of a relation of trust between organization and legitimising actors, as well as on the decision-making process within the organization, the inclusion of the points of view of the legitimising actors and the final results created by the organization.

The relationship among the actors surrounding the international organization is basic for the construction of the social legitimacy of the organization, since the debates and discussions among states impact on their perception of the legitimacy of international agency and institutions ${ }^{39}$. This way, an international organization is understood as a set of relatively stable identities and interest ${ }^{40}$. It is a normative structure that may or may not have coercive force and, therefore, its principal value to the actors receptors of its activity and authority depends on the socialisation and participation in the collective knowledge. In fact, if it is possible to point out some common and crucial characteristics of international organizations, it is crucial to stress that each of one has it's one objectives, internal structures $^{41}$, and social identities and interests.

\section{(b) International organizations as international political community}

The question of the legitimacy of international organizations has not previously been treated in great detail, since the expectations of states and citizens have been assumed low and the sentiment of community in the international arena insufficient ${ }^{42}$. Still, the notion of social legitimacy is sustainable because of the emergence of a kind of global political communities ${ }^{43}$ around international organizations. This global political community is characterised by including both the international organization itself, its member states and the citizenry, the latter being vital for the consolidation of the political community. A second characteristic is the generalised agreements among these actors that a political community exists among them, which to some authors constitutes in itself a horizontal dimension of legitimacy ${ }^{44}$ as the non forced ability of a political power to obtain compliance. A third characteristic of the global political community surrounding an international organization is the

\footnotetext{
38 B. Tholen, "RIOs legitimacy and democracy. A conceptual clarification", in A. Ribeiro y A. Vleuten van der (eds), Closing or widening the Gap? (Hampshire, Ashgate, 2007) I7-3I, at 2I-23.

39 J. Mitzen, "Reading Habermas in anarchy: multilateral diplomacy and global public spheres", 99 (3) American Political Science Review (2005) 40I-4I7, [doi: 10.1017/S0003055405051749].

40 Wendt, supra n. I9, at 9.

4I Legal personality of each international organization should be fixed in its internal rules: Vienna Convention on the Law of Treaties between States and International Organizations or between International Organizations (adopted 2I march 1983, not entered in force yet) N/A UNTS, Art.2(I)(j), Art. 5 and Art. 6. In this sense, we will find also some differences between regional and universal international organizations (J.M. Sobrino Heredia, supra n. 4, at 49-5I), and also analysing the degree of political delegation made by the states or the power of their decision-making authority (Rittberger and Zangl, supra n. 5, at II-I2).

42 Coicaud, supra n. IO, at. 2I.

43 Payne and Samhat, supra n. I2, at 27.

44 I. Svensson and M. Lindgren, "Community and consent: Unarmed insurrections in non-democracies", I7 (I) European Journal of International Relations (20II) 97-I20, at I02 [doi 10.I177/1354066109350049].
} 
shared knowledge of the reasons why the community exists and the procedures of the organizations in order to obtain information to aloud access of a suitable reflection.

In fact, the notion of community is inherent in the notion of legitimacy, since the latter refers to a social quality constructed through interaction within a group as well as to the structures of this group and the forms of interaction of its members ${ }^{45}$.

This way, the idea of a political community underlines the possibilities for the social actors to reconfigure the relevant political sphere through dialogue and the acquired collective commitments ${ }^{46}$. The social legitimacy of the political community surrounding an international organization depends on the interaction of the organization with the other members of the community, the legitimising actors. As a public sphere, the political community needs that the examined authoritative actions of the IO are visible and that a debate about them is possible, so that each can construct an opinion about specific actions and the organization itself47. The political community is created by the discourses produced within it, since the "space where discourses are produced is a sphere of political and social action" ${ }^{48}$. The global political community thus offers an international organization's legitimation process built on the basis of public debate around shared principles and values.

The global political communities are formed around international organizations as reflections of the common values of its members, which are both states and citizenries. The most prominent characteristic of the global political community is, apart from its multi-subjectivity, the interiorisation of a specific structure of authority and the norms flowing from this ${ }^{49}$. The idea of a global political community thus entails that the actors enduring the authority, states and citizenry in this case, share a common vision. It implies, definitely, that a notion of social legitimacy results from the internal dialectical processes within all the actors of the community

The global political community is structured around common multilateral norms. Multilateralism is the source of international institutions, their organization and, most importantly, their consolidation, not based on the particular interests of the founding states, but common principles ${ }^{5 \circ}$. The common principles refer not only to moral standards, but also to the procedures and effectiveness of the international organization. In this sense, it is the behaviour of the international organization that creates its image and contributes to construct its identity. Through its activities, the international organization establishes behavioural standards and norms $\mathrm{s}^{\mathrm{sI}}$, which constitute frames of meaning shared by the actors of the political community and include a shared vision that influences the behaviour of states and citizenries. The emergence of a global political community with a legitimate political authority thus requires that the rules upon which the authority is based are interiorised by all the members of the community, constructing a perception of legitimacy in international organization's social sphere.

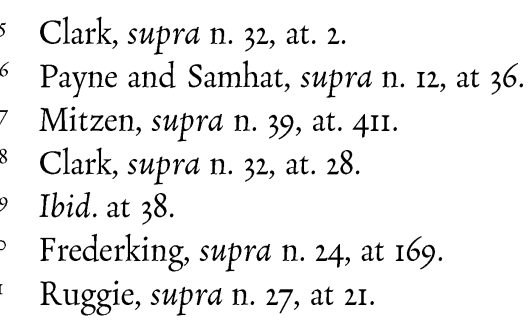


In this sense, what is remarkable about contemporary multilateralism is not only that it coordinates national policies but also the fact that this coordination takes place on the basis of some principles that govern the relations among states $^{52}$. This means that the activity on a multilateral level, and particularly within international organizations, is governed with a basis in the perception that shared principles are respected and so, national interests are no longer the only explanation to international behaviour. In other words, the notion of social legitimacy implies recognising the centrality of the beliefs of the actors of the political community surround an international organization. This centrality stems from the recognition that state and non-state actors are capable of creating and reforming social structures ${ }^{53}$. The sources of the legitimacy of international organizations thus include the public recognition of their right to regulate a given area and the predisposition to comply of the legitimising actors which are the passive subjects receptors of the rules promoted by the IGO.

In sum, international organizations are here considered global political communities wherein states and citizenries share the principles, values and objectives sustaining the community as well as the conscience of being capable of modifying the common perceptions of reality. In turn, social legitimacy is a non-material characteristic of international organizations that furthers compliance with its decisions and rules. It is based on the subjective perceptions of the other actors of the political community of three dimensions: the moral values of the organization, the principal of legality and the effectiveness of the organization. The perceptions of the legitimising actors, states and civil society organizations, can be studied through discourse analysis.

\section{(C) THE SOCIAL LEGITIMACY OF INTERNATIONAL ORGANIZATIONS}

As detailed above, to estimate the social legitimacy of an international organization, it is necessary to analyse both subjective and objective dimensions. The subjective dimension of the analysis involves identifying the relevant legitimising actors within the political community surrounding the international organization. In second place, is necessary to go deep with the object of the exam done by legitimising actors: the objective dimensions. These ones are an ideal image of the IGO behaviour for legitimising actors.

The legitimising actors perceive an international organization as legitimate as a function of how the organization performs with respect to three aspects: I) the respect for the moral values and social objectives of the organization; 2) behaviour according to the principle of legality and 3) effectiveness. The objective dimension is divided in three aspects because they resume how the IGO behaviour is. This behaviour represents the common knowledge of what the international organization means for the legitimising actors. The subjective dimension of the analysis identifies the perceptions of the organization with respect to these three aspects of each legitimising actor, through an analysis of their discourses.

52 J.G Ruggie, Multilateralism matters. The theory and praxis of an institutional form (New York, Columbia University Press, 1993).

53 A. Linklater, Transformations of Political Community (London, Polity Press, 1998), at I8-22. 
This way, the international organization behaviour is continuously held accountable by legitimising actors, states and civil society organizations. The result of this analysis is what determines the degree of legitimacy of an international organization in a given moment (see figure $\mathrm{I}$ ). Legitimising actors make dynamics of accountability in order to analyse objective criteria, not legitimacy. The result of those dynamics will form each actor's legitimacy impression which it would express in their public discourses.

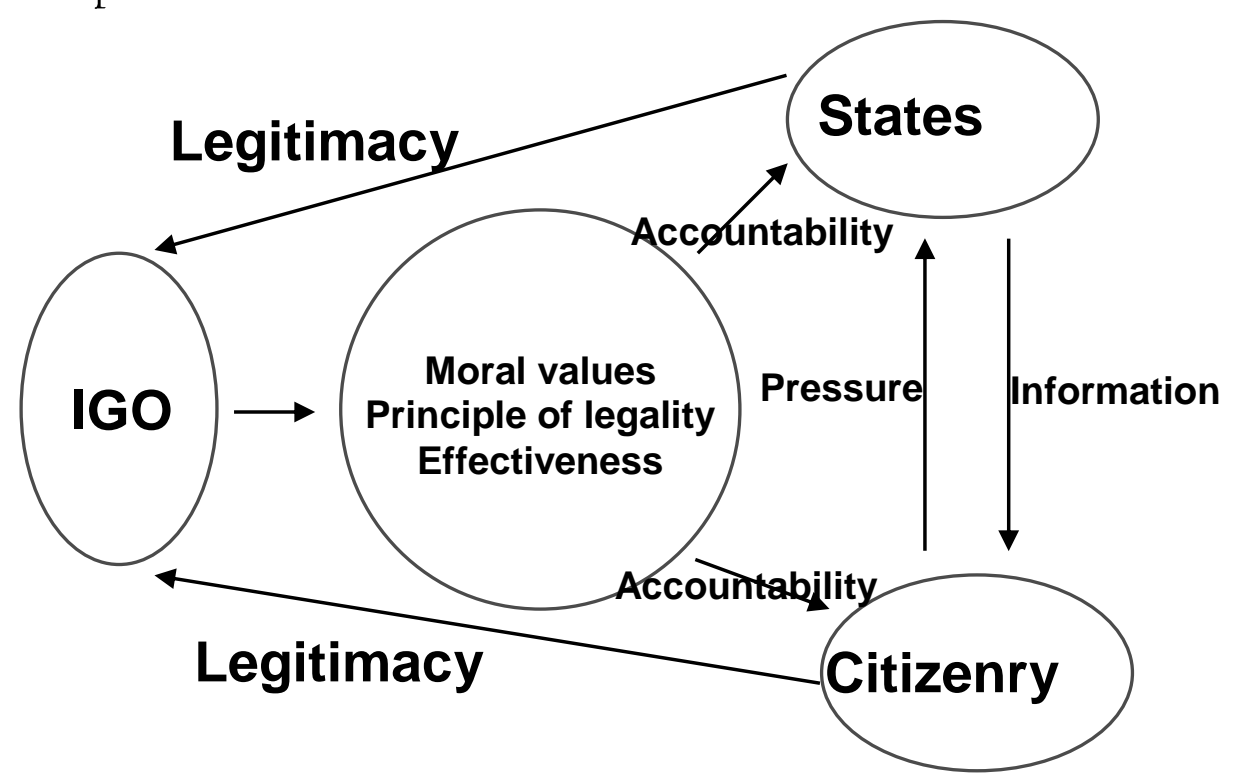

Figure I: The creation of social legitimacy of an international organisation ${ }^{54}$

This way, the notion of social legitimacy, centered on the perceptions of the legitimising subjects with respect to the behaviour of the organization, includes both input legitimacy and output legitimacy, as defined by Krajewskiss (200I, I69). These concepts consider legitimate the norms produced by a political system if they are based on the fundamental principles of the subjects of this system. The principles can either define conditions relative to the procedure bywhich norms are created or the conditions by which to measure the material results obtained. The concept of social legitimacy includes both aspects, since it implies taking into account both how norms are created (input legitimacy or principle of legality) and the effect of these (output legitimacy or effectiveness)..$^{56}$ The fundament principles and values, the third aspect mentioned in the social legitimacy definition proposed above, are in Krajewski's notion of legitimacy additional to the input and output legitimacy. It is important to underline the social nature of all three kinds of legitimacy. As such it is perfectly possible for an organization to follow establish procedures in its decision making and obtain its official goals, but nevertheless be socially illegitimate if the goals obtained and procedures followed are

54 Source: Gutiérrez-Solana, supra n. 6, at 5I.

55 M. Krajewski, "Democratic legitimacy and constitutional perspectives on WTO Law", 35 (I) Journal of World Trade Law (200I) I67-I86, at I69.

56 The concept of input legitimacy is to other authors a criterion relative to the collective decision-making process towards the common good, thus including also criteria of public participation in governance (see A. Ribeiro y A. Vleuten van der (eds), Closing or widening the Gap? (Hampshire, Ashgate, 2007).) 
not in line with the moral values of the legitimising actors and what these see as the relevant goals procedures that should be followed.

The three objective aspects that are used in this analysis are similar to those proposed by Cronin and Hurd ${ }^{57}$. But along with Krajewskij ${ }^{8}$, they consider that it should be objectively established by the researcher whether the moral values, internal procedures and impact of the organization are legitimate. What is proposed here is not to analyse what really happens in the international organization, but how the relevant legitimising actors perceived what is happening. The notion of social legitimacy is thus decoupled from the direct and objective assessments of the legitimacy of international organizations by researchers.

The social construction of the legitimacy of international organizations is understood as a dynamic process among the subjective perceptions of the legitimising actors of the political community surrounding the international organization. The dynamism is due to the fact that the legitimacy of an international organization is not static, but a quality continuously attributed (or not) to the organization as a function of its behaviour relative to certain objective criteria (which have to resume IGO's social functions).

Nevertheless, beyond objective dimension that describe the behaviour of an international organization, what is fundamental for the consolidation of the legitimacy of an international organization is the dual (the one offered by states and the one offered by citizenry) subjective perception of the analyst. The basis is the supposition that the social reality of the political community surrounding an international organization consists in that the members of the community construct social meanings through discursive practices 59 , and thereby the legitimacy of the organization as argued above, thereby the notion of social legitimacy is not defined in terms of a predefined prescriptive essential content. In contrast, social legitimacy depends on individual convictions expressed and observed in collective way about the appropriateness of a concrete expression of governance or authority. These convictions are neither uniform nor consensual but vary according to the subject holding them ${ }^{60}$ and the time at which they are articulated.

This analysis differs from the classic analysis of state legitimacy by citizens and also from the majoritarian state centrism in the field of International Relations with respect to the legitimacy of international organizations. The present analysis parts from the observation that the functioning of international organizations not only affects states and, further, from the observation that states do no directly control international organizations. As is the case of the state, the citizenry is also affected by international organizations directly and it acts (or his representatives do) consciously to influence these. The relationship among international organizations, states and citizenry is triangular, as

57 Cronin and Hurd (eds), supra n. I7.

58 Krajewski, supra n. 55 .

59 Frederking, supra n. 24. In some way, we are analysing how "the audience" reacts to the behaviour and discourses of international organizations (See: S.B. Rasmussen, "The conceptual field of contemporary public diplomacy", or Comillas Journal of International Relations (2014) I-39, at 35-36 [doi: cir.ior.y2014.003]

60 T. Diez, M. Jachtenfunchs, and S. Jung, "Which Europe? Conflicting models of a legitimate European political order", 4(4) European Journal of International Relations (1998) 409-445, at 4I3 [doi: 10.I177/1354066198004004002]. 
observed by Steffek ${ }^{6 \mathrm{I}}$ when he analyses relationship between international norms, states and citizenry. In consequence, whichever analysis of the legitimacy of an international organization should adopt this double (including both states and citizenry's perceptions) subjective analysis in order to obtain a precise knowledge of the legitimacy of the organization.

\section{(I) The legitimising actors in International Organizations:}

\section{(a) Legitimising actors. The state}

The estimation of the legitimacy of an international organizations made by states is, of course, fundamental. International organizations are, after all, created by states. The states are founders and members of the international organizations, and thereby also partially responsible for their functioning. Nevertheless, the individual state is also the receiving subject of the legal obligations created by international organizations, and therefore carefully decides which international organizations of which to become a member or help create. ${ }^{62}$

It is necessary that the state assumes and shares the vision of a given international organization as a legitimate political entity since, in the opposite case, the state could destabilise the regime by not complying with its obligations or by leaving the organization. The generalised compliance with the obligations stemming from international organizations seems to indicate a perception that compliance is in the general interest ${ }^{63}$. Thereby, the organization gains credibility. Legitimacy has a prescriptive dimension that increases compliance ${ }^{64}$ and, as a consequence of this, the assumption of obligatory compliance rests upon the analysis of legitimacy. More legitimacy perceived, more tendency to obey. The estimation of a certain degree of legitimacy supposes for the state the moral conviction that compliance is the correct course of action, a conviction that leads to the acceptance of the power of a superior external authority based on values, norms and principles ${ }^{65}$.

A state bases its estimation of the legitimacy of an international organization on a continuous analysis of the activities of the international organization in question, a process which amounts to a permanent process of accountability. At the same time, the state is active within the international organization, in order to make it fulfil the three objective dimension of legitimacy and to influence the output of the international organization.

The study of the foreign policy of a state, as expressed in its discourses, allows analysing how it perceives of an international organization in terms of legitimacy, since it connects the material and ideational spheres ${ }^{66}$ and gives importance to what is publicly expressed for the construction of public images ${ }^{67}$. The perception by a state of an international organization as legitimate is not automatic, nor

6r J. Steffek, "Legitimacy in International Relations. From State Compliance to Citizen Consensus", in A. Hurrelman, S. Schneider and J. Steffek (eds), Legitimacy in an Age of Global Politics (New York, Palgrave, 2007), at I89.

62 D. Donno, "Who is Punished? Regional Intergovernmental Organizations and the Enforcement of Democratic Norms", 64 (4) International Organization (2010) 593-625, [doi: 10.1017/S0020818310000202].

63 D. Luff, Le Droit de l'Organisation Mondiale du Commerce (Brussels, Bruylant, 2004), at 98I.

64 Miyaoka, supra n. I7.

65 Hurd, supra n. II, at 394-399.

66 L. Hansen, Security as practice. Discourse Analysis and the Bosnian war (Oxoon, Routledge, 2006).

${ }_{6}$ B. Buzan, O. Waever and J. de Wilde, Security. A new framework for analysis (London, Lynne Rienner Publishers, 
uniform. A first indicator hereof is the activity level of the state within the international organizations: an active participation constructs an image of the international organization as a legitimate institution of governance ${ }^{68}$, while the passivity of the state reflects a negative perception of the organization.

The process of accountability is basic for an examination of legitimacy ${ }^{69}$ and here it is the state that has the easiest access to information about whether the international organization complies with its legitimacy dimensions. For this access to be optimal it is necessary that the international organization functions with a high degree of transparency, which the member states actively supervise the organization and that fiscal mechanisms have been implemented, which allow the states to hold the organization accountable ${ }^{70}$. Therefore, it is important to create mechanisms at state level that help to control state activity in international organizations. This control can be improved on two levels. One possibility is through the organization of parliamentary debates about the nature and role of state delegations to international organizations. A second option is to give more importance to state participation in international organizations and assuring the quality of the work done the by state delegations ${ }^{7}$.

The legitimacy of an international organization in the eyes of a member state thus depends on the quality of the process by which it can hold the organization accountable as well as on the trust between the political entities. This image is going to be public through state's public discourses about the International Organisation building the ultimate and social perception about its legitimacy.

\section{(b) Legitimising actors. Citizenry and global civil society}

The inclusion of the citizenry as a legitimising actor of international organizations means including, in principle, all the subjects of the political community. The lack of a citizen's vision of international

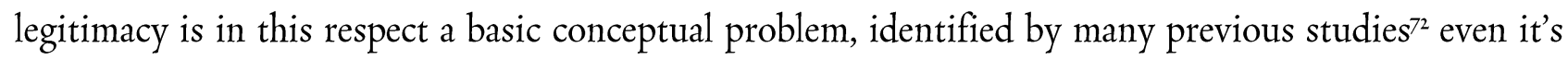
not yet a pacific matter in the area ${ }^{73}$.

In spite of being clearly state centered, international organizations are at the core of a global political community where the global citizenry plays an important role. The citizens are present in the life of international organizations, are the final receivers of the rules and norms created by them and

1998).

68 D. Lee, "South Africa in the World Trade Organization" in D. Lee, I. Taylor and P.D. Williams (eds), The new multilateralism in South Africa (New York, Palgrave McMillan, 2006), at 59.

6. Keohane and Nye, supra n. 8.

70 Keohane, supra n. 8, at 83-86.

71 P. Jacquet, J. Pisani-Ferry, y L. Tubiena, Gouvernance mondiale (Paris, Documentation Française, 2002), at 49.

72 See: I. Clark, "Legitimacy in International or World Society?" in A. Hurrelman, S. Schneider, J. Steffek (eds) Legitimacy in an Age of Global Politics (New York, Palgrave, 2007); D. Bodansky, "The legitimacy of international governance: A coming challenge for international environment law", 93 (3) American Journal of International Law (1999) 596624, [doi: [0.2307/2555262]; M. Zürn, "Global Governance and legitimacy problems", 39 (2) Government and Opposition (2004) 260-287, [doi: 10.سW/j.I477-7053.2004.00I23.x]; J. Steffek, supra n. 6r;

73 See: H. Agné, L.M. Dellmuth, and J, Tallberg, "Does stakeholder involvement foster democratic legitimacy in international organizations? An empirical assessment of a normative theory", Io (4) The Review of International Organizations (2015) 465-488, [doi: 10.1007/su558-014-9212-6]. 
constitute an important external pressure group that conditions policies and agendas. ${ }^{74}$ Although drawing a direct analogy between the state citizenry and the global citizenry would be incorrect, a cosmopolitan notion of global citizenry, identified as the obligation to maintain certain common principles by consensus ${ }^{75}$, helps to understand the necessity of investigating citizen's perceptions of the behaviour of international organizations because those perceptions must be consensual and strong. Nevertheless, the ability of the citizens to obtain information and achieve a common position on questions as complex as the legitimacy of international organizations is obviously limited. This common position, or legitimising consensus ${ }^{7}$, among citizens arises out of rational public debate, and is the source of the individual's feelings of acceptance with respect to an international organizations. This rational debate is centered on the procedures and values of international organizations ${ }^{77}$, as well as usefulness of the organization, conceptualised as its effectiveness.

Still, the citizenry as such does not have the capacity to reach a legitimising consensus. Therefore, the analysis centeres on the perceptions of civil society organizations, since these are the only organised representations of the citizens other than the state, and they have an alternative political discourse and acts in their own right in the necessary dynamics of rational and institutional debates. The drawback is that these civil society organizations are not simple representations of the citizenry, but have each their own vested interests ${ }^{7}$, and therefore, their perception is obviously not objective. NGO's and social movements, as civil society organizations, have a unique function in global politics, namely that they socialise the articulation of global ethical patterns on a global level79. This way, the perception of the legitimacy of an international organization, as expressed by civil society, can rapidly penetrate the perceptions of citizens, and therefore tend to be similar.

The virtue of the conviction that civil society is a legitimising actor with respect to international organizations is its closeness to a genuine representation of humanity, since it is not linked to a specific limited territory but only more generally to the interests of the peoples of the world. Obviously, this representation of humanity does not exist formally, but nevertheless, when the aim is to gain knowledge of the opinion of global civil society, NGO's and social movements come closest.

Given the fact that the traditional forms of dialogue between civil society and the state are gradually losing effectiveness, new forms of citizen action are emerging with the aim of controlling the forces that directly affect the population, including emerging regional and global regimes as well as private

74 See: A. Gutiérrez-Solana, "La imposible legitimidad del G-20 a la luz de las propuestas cosmopolitas" in C. Garcia Segura (dir), La tensión cosmopolita. Avances y límites en la institucionalización del cosmopolitismo (Madrid, Tecnos, 2016) 215240; C. García Segura, "La "mirada cosmopolita" como requisito político y social para la provisión de los Bienes Públicos Globales", i6 AFDUAM. La Protección de Bienes Jurídicos Globales (2012) 55-74; P.T. Stoll "Global Public Goods. Some considerations on actors, structures and institutions", 3 Global Legal Goods Working Paper (20II).

75 Payne and Samhat, supra n. I2, at 38.

76 Steffek, supra n. 6I, at i89.

77 See: J. Steffek, “The legitimation of international governance: a discourse approach", 9 (2) European Journal of International Relations (2003) 246-275, at 267 [doi: I0.1177/I354066103009002004]; N. Cornago, "Problemas de legitimación del nuevo régimen mundial del comercio: una exploración para internacionalistas” in J. M. de Faramiñán (coor) Globalización $y$ comercio internacional. Actas de las XX Jornadas de la AEPDIRI, (Madrid, BOE, 2005), at 225..

${ }_{78}$ J. Casquette, Política, cultura y movimientos sociales (Bilbao, Bakeaz, 1998), at 28; D. Bodansky, supra n. 72.

79 Payne and Samhat, supra n. I2. 
multinational interest which, often, are stronger than nations ${ }^{80}$. In this context, the consolidation of the global civil society is the answer of civil societies to international changes, globalisation and interdependence.

As a frame of reference, global civil society can be understood as a network of social movements with different spheres of action (local, national, regional) in an international perspective ${ }^{8 \mathrm{I}}$, and that may act together on specific occasions or cooperate more strategically. The diversity of organizations, movements and ways of understanding social agency is one of the key characteristics of the new transnational civil society. Global civil society constitutes an external pressure group seeking influence in the state, the market, the private corporations and intergovernmental institutions ${ }^{82}$.

Civil society thus includes different types of social movements. Firstly, it includes the traditional movements of workers and peasants, which not only act within a state but also internationally. The strategy is to influence and ultimately transform state structures through mass mobilizations. Secondly, civil society also include the "new social movements" ${ }_{3}$ that are less concerned with traditional political and focus on specific and global issues, such as ecologist and feminist movements. Their aim is to influence both public opinion and more directly where important decisions are made. A third kind type is constituted by the "newest social movements" ${ }^{4}$. They are solidarity movements whose activities include international development aid, the defence of immigrants' rights, solidarity with socially excluded persons etc. Lastly, there is the so-called antiglobalisation movement, which includes elements from the other three types as well as leftist political organizations, indigenous groups, religious groups, alternative peasant organizations and specific groups, such as ATTAC and RCADE. Global civil society exists as a diffuse subject between the national and the international spheres, and between the public and private spheres $^{85}$. The global civil society organizations place demands upon the states, but also act in the international sphere by putting pressure on multinational corporations to change their practices and on international organisations to impact on the multilateral level. From a constructivist perspective, their activities are aimed at "influencing transnational social practices" ${ }^{\prime 6}$, and at same, are influenced by these very practices.

Global civil society is a sphere in which individuals or groups voluntarily participate and create social relations through their promotion of shared interests and values ${ }^{87}$. Global civil society actors have a great capacity for putting issues on the international political agenda ${ }^{88}$ by circumventing formal bureaucratic channels that tend to delay decision making, if not postponing it indefinitely ${ }^{89}$.

\footnotetext{
so J. Grandi, "Ciudadanía, entre la globalización y la integración" in B. Podesta (coord), Ciudadanía y Mundialización. La sociedad civil ante la integración regional" (Madrid, Cideal, 2000).

8I M. Kaldor, Global Civil Society (Cambridge, Polity, 2003) at 76.

82 A. Serbin, "La sociedad civil transnacional y los desafíos de la globalización", in B. Podesta, (coord), Ciudadanía y Mundialización. La sociedad civil ante la integración regional” (Madrid, Cideal, 2000), at. 29; Kaldor, supra n. 8I,. at. 44.

83 Serbin, supra n. 75 , at. 27.

${ }_{4}$ P. Ibarra, Manual de sociedad civil y movimientos sociales (Madrid, Síntesis, 2005), at. 26I.

85 J. Clark, Worlds apart. Civil society and the battle for etbical globalization (Connecticut, Kumarian Press, 2003), at 95.

86 Payne and Samhat, supra n. I2, at 44.

87 P. Wapner, "Civil Society" in T.G. Weiss and S. Daws (eds), The Oxford Handbook on the United Nations (New York, Oxford University Press, 2007) at 255.

88 R. C. Carpenter, "Vetting the Advocacy Agenda: Network Centrality and the paradox of Weapons Norms", 65 (or)
} 
Apart from ability to direct political attention to urgent issues through visible, and at times spectacular, actions, another important aspect is the capacity to create and diffuse a series of international norms (human rights, ecology etc.). These norms are by their nature not mandatory for governments and other powerful actors to follow, but nevertheless, ignoring them seriously harms their public image. At the same time, the norms have en educational effect on the citizenry ${ }^{\circ}$.

The role played by global civil society actors in the construction of the image of legitimacy of an international organization can be ascertained through an analysis of the discourse of these actors on the three objective criteria identified above with respect to a given international organization. The information diffusion activities of NGO's and other social movements and their participation in public debates about the objective criteria identified construct a legitimacy image of an international organization, as seen by citizenry, underlining the faults and strengthening the positive sides ${ }^{9 \text { I }}$. There is a tendency to think that NGO's participate in global governance because they have gradually been incorporated in the debates of international organizations and because they have had an influence in how these organizations become more transparent and are held accountable ${ }^{92}$. Nevertheless, NGO's generally participate in the debates of international organizations by invitation only, with limited access to information and only in specific debates about certain issues ${ }^{93}$. This is seen, for instance, in the debates of UN sectorial conferences and in WTO debates.

It is easier to analyse the legitimacy of an international organization if the latter is open for citizens to exercise control over its functioning. It is here important to note that this control does not need to be institutionalised. The capacity of civil society to influence in the construction of the legitimacy of an international institution is an example of such a process of control, which is why the influence of civil society in the functioning of an international organization goes beyond mere participation in internal processes ${ }^{4}$. Global civil society, in a discursive perspective, maintains the capacity to fix the legitimacy of processes, principles, norms and objectives of an international organization, irrespectively of the inclusion of certain organizations in the internal processes of the organization, although this formal conclusion has been on the rise lately ${ }^{95}$. The existence of a structured debate between the organization and civil society actors logically facilitates the construction of consensual norms and values, but it is not a necessary condition.

In consequence, the social legitimacy of an international organization depends on the perception of civil society actors, and is reflected in the discourse of these actors towards the exterior. The

\footnotetext{
International Organization (20II), 69-IO2, [doi: 10.1017/S0020818310000329].

89 A. Florini, The coming democracy. New rules for running a new world (Washington D.C., Brookings Institution Press, 2005), at I4I.

90 Ibarra, supra n. 84, at 276.

$9 \mathrm{~J}$ J. Casquette, "Movimientos sociales y democracia", 55 Cuadernos Bakeaz (2003), at 4.

92 M. Abad, ¿Una alternativa solidaria frente a la barbarie? Las ONG en la nueva sociedad global (Madrid, CIDEAL, 2004), at 97.

93 A.-K. Lindblom, Non-governmental Organizations in International Law (Cambridge, CSICL, 2005), at 446.

94 K. Ghimire, "The United Nations world summits and civil society activism: Grasping the centrality of national dynamics", I7 (OI) European Journal of International Relations (201I) 75-95, [doi: 0.II77/I354066109344660].

95 B. Reinalda, "The question of input, control and output legitimacy in Economic RIOs" in A. Ribeiro y A. Vleuten van der (eds), Closing or widening the Gap? (Hampshire, Ashgate, 2007) at 56.
} 
legitimacy of an international organization therefore does not depend on whether it complies with the above-mentioned objective criteria, but whether states and civil society actors perceive it to be complying with them.

\section{(2) The objective dimensions of legitimacy}

Having identified the legitimising actors, the next step is now to examine the objects that these actors interpret in order to reach their perception of the legitimacy of an international organization. These three dimensions relate to all the facets of the behaviour of international organization, and it is the perception of the performance of the international organization with respect to those that determines the social legitimacy of the international organization.

\section{(a) Moral values}

First and foremost, moral values are the basis of the multilateral system and its social objectives. They are the principles that allowed inter-state cooperation begins in the first place and to continue to prosper. Moral values can also be seen as the common principles that represent the overall vision of justice ${ }^{96}$, and to reach an agreement on moral values is therefore a basic necessity for any social group. In the case of international organizations, their moral values are a basic part of their reason for being. International moral values are tend to be explicit and are usually presented as international principles shared by all members of the international system ${ }^{97}$, even though doubts exist about the possibility of specifying them in any detail ${ }^{8}$.

Common moral values exist from the moment in which stable international organizations are established as political communities. In this respect, the function of the analysis done by legitimising actors is to supervise the respect for themselves y and also to control the non-enlargement to others less shared. According to Clark ${ }^{99}$, international principles are so strong that their acceptance is a requisite for membership of international society and, in consequence, of international organisations.

Nevertheless, moral values are not static principles that must necessarily be complied with, but rather the core around which the social objectives of the international organisation develop and, therefore, moral and shared values are the real reason for the existence of international organisations. The legitimacy of an international organization depends on whether the legitimising actors see a clear and direct concordance between the objectives and values of the organizations. As stressed by ${ }^{\text {roo }}$ Bernstein (2004), the legitimacy of an international organization depends on whether its policies and actions reinforce the common objectives (inspired by moral values) and are supported by its members.

The construction of the opinions of the legitimising actors about the moral values of an international organization depends on their impression of the relationship between the values and

96 See: J. Habermas, Problemas de legitimación del capitalismo tardío (Madrid, Ediciones Cátedra, I999), at I65-I71; R. M. Dworkin, "Obligations of Community" in J. Raz (ed), Authority (Oxford, Blacwell, 1990), at 236-238.

97 J.M. Coicaud, "International Organizations, the evolution of international politics, and legitimacy" in J.M. Coicaud and V. Heiskanen, The legitimacy of International Organizations (New York, United Nations University Press, $200 \mathrm{I}$ ), at 537.

98 Buchanan and Keohane, supra n. II, at 409-42I.

99 Clark, supra n. 32, at 173-174.

roo S. Bernstein, "The elusive basis of legitimacy in global governance", 4 (O2) UIGHC Working Papers (2004), at 19. 
objectives of the organizations and, above all, on the concordance with the values and objectives of those actors. In fact, states continuously monitor if this concordance is still intact, supposing that it existed at the moment of the establishment of the international organization, and civil society actors ask themselves whether the concordance exists at all.

\section{(b) The principle of legality}

The second objective dimension is the principle of legality, since legitimising actors continuously estimate whether an international organization functions lawfully. This dimension is fundamental, although legality in itself is not sufficient to guarantee legitimate authority. On the contrary, legality is only a legitimising factor when part of a wider framework taking into account the moral values of the organization and its political project ${ }^{\text {tor }}$.

The conviction of the legitimising actors that the international organization adheres to the basic elements of the principle of legality strengthens their perception of the organization as legitimate. These elements can be divided in two facets. Firstly, the conviction that the organization acts within the competences that was attributed to it by the legal instrument creating it. Here state delegation of power and consent to fulfil its functions are fundamental for the capacity of the international organization to act legally and for the creation of a widespread perception that this is $\mathrm{so}^{\text {I02}}$. These are aspects that derive from the pact between men to be ruled that sustains obedience according to Hobbes $^{\mathrm{T}}{ }^{3}$. Secondly, the legitimising actors estimate both whether the formally established procedures follow general legal principles, which is the classic weberian perspective of legitimacy, and the degree to which the actual functioning of the organization follows the formal procedures. The main development of this perspective, from the point of view of International Law as a discipline, was basically achieved by Thomas Franck ${ }^{104}$ : although his work reflects an erroneous comparison of procedure with justice, it also underlines that international norms must be considered, by the legitimising actors, relative to established procedures, in order to be seen as legitimate. As such, the principle of legality implies that an act considered illegal is automatically also considered illegitimate ${ }^{\text {tos }}$ and it's possible to say that legality is a necessary but not sufficient condition for legitimacy.

Procedural rigour is thus basic to strengthen the legitimacy of international organizations, and as such, the organizations themselves. An extensive, clear and objective internal legal procedure that includes technical points of view and eliminate arbitrariness evidently can increase the legitimacy of the institution ${ }^{\mathrm{ro}}$. A correct and respected internal procedure, not only offers adherence and guarantee

ror O. Corten, Le discours du Droit international. Pour un positivisme juridique (Paris, Editions Pedone, 2009), at 136.

זо2 Zaum, supra n. 7, at 457.

${ }_{103}$ T. Hobbes, Leviatán (Móstoles, Editora Nacional, 1983).

${ }^{104}$ Franck, supra n. 7, at 49. See also the conflict between legitimacy and legality notions which often emerges in collective military actions: A. J. Rodrigo, "Between old rules and new practices: Spanish practice on the use of force (I99020I5)", I9 SYbIL (2015) 329-345, at 331-332 [doi: I0.17I03/sybil.19.24]

ros A. Pellet, "Legitimacy of legislative and executive actions of international institutions" in R. Wolfrum and V. Röben (eds), Legitimacy in International Law (Berlin, Springer, 2008), at 72.

Io6 Esty, supra n. 7, at I56I. 
to the states, but it is also important for citizens as a criteria for abiding by the norms diffused by the international organizations and as a sign that their rights can be respected ${ }^{\mathrm{I} 07}$.

The analysis made by legitimising actors is based on their perception of the legal structure of international organizations and general legal principles. Also influencing their perception is their knowledge of what an international organization is and what it has to offer. To summarize this notions, The International Law Association ${ }^{108}$ resumes the principles, objectives and concepts common to all international organizations as: good governance, good faith, constitutionality and institutional balance, supervision and control, rational decision making, respect for procedures, objectivity and impartiality and, finally, due diligence. As it's evident, this list includes both objective dimensions so far explained: moral values and principle of legality. The knowledge of all these imply a previous image of the organization with which legitimising actors estimate the degree to which international organizations respect the variables of the principle of legality.

\section{(c) Effectiveness}

As the third dimension, the effectiveness of international organizations relates to the usefulness of the institution. In their construction of their legitimacy perception of an international organization, states and civil society analysis the degree to which the organization reaches its objectives. Effectiveness supposes, on one hand, the capacity to exercise authority actively and, on the other hand, the effectiveness of the undertaken actions. This dimension links legitimacy with results, as proposed by Scharpf fiog and therefore the legitimacy degree of this dimension will depends on what legitimising actors (each state or each member of global civil society) expected and perceives. So, an action augments the legitimacy of the international organizations if has been undertaken according to the values and principles of the organization, and if it helps to reach pre-established objectives ${ }^{\text {IIO }}$. In contrast, legitimacy decreases when actions have unforeseen negative effects or when the organization is unable to act and a rival institution emerges ${ }^{\mathrm{III}}$.

Effectiveness, characterised as a criterion of output legitimacy ${ }^{\mathrm{II}}$, implies studying the achievements of an organization taking into account its material capabilities. Consequently, in order to establish realistic expectations, it is necessary to identify both the various objectives of the international organization and the means it has at its disposal to achieve these. It is on the basis of such an analysis, the legitimising actors estimate the effectiveness of the organization, as it can be observed after study

\footnotetext{
107 N. Bobbio, "Sur le principe de légitimité" in P. Bastid et al., L'idée de légitimité (Paris, Presses Universitaires de France, 1967), at 49.

I08 International Law Association, "Accountability of International Organisations", Berlin Conference Final Report (2004) at 8-15, accessed 28 july 2016

Io9 F.W., Scharpf, “Conceptos de legitimación más allá del Estado Nación”, I3 Revista Española de Ciencia Política (2005), at $15-22$.

II Reus-Smith, supra n. 3I, at 165; J. Steffek, "The output legitimacy of international organizations and the global public interest", 7 (2) International Theory (2015) 263-293, [doi: http://dx.doi.org/10.1017/S1752971915000044]

III F. Battisti, "Erosione e riconstruzione della legittimitá" in A. Carbonaro (ed), La legittimazione del potere. Problemática del rapporto tra Stato, istituzioni e societá (Milán, Franco Angeli Libri, 1986), at 106.

II2 See: Krajewski, supra n. 55, at I69; Ribeiro and Vleuten, supra n. 56.
} 
legitimising actor's public discourses about effectiveness ${ }^{\mathrm{II} 3}$. Therefore, because international organization most often have concrete objectives, when an international organization is inactive or engages in ineffective or detrimental practices, this is very damaging to its legitimacy in the eyes of states and civil society because they could see them as irrelevant organizations

\section{(D) CONCLUSION: LEGITIMACY AS A SOCIAL PERCEPTION}

The aim of this article was to outline a theoretical framework to analyse the legitimacy of international organizations. A social notion of legitimacy was theoretically developed and operationalized as an analytical tool.

The international intergovernmental organizations have been described as international regimes with characteristics of a global political community ${ }^{\mathrm{II}}$, and this is important as it involves the acceptance of a social internal life of its own within the community, a group of different actors and roles where all the state agents like citizens and international organizations participate. A community based on multilateral rules acknowledged by the actors. This community, which is a heterogeneous political system, turns its rules into political cultures predetermined that limit and specify the field of legitimacy. Thus, based on the political culture the community creates an image of authority that perfectly matches the cultural pattern ${ }^{\mathrm{II}}$.

At the same time, another basic assumption of the social legitimacy notion is understanding the idea of legitimacy as an ideal field and not as a material field of the international relations ${ }^{\mathrm{II}}$, as the impulse to fulfil obligations coming from an organization holding that quality ${ }^{\mathrm{II}}$, where the conclusions are not in previous dimensions and conditions but in the common knowledge built in the actors' interaction $^{\mathrm{II}}$. Thus, the preconceptions about the meaning of legitimacy of an IGO or what it has to do to be considered legitimate are disregarded.

In conclusion, the concept of the IGO's social legitimacy implies the existence of a specific social group comprised of the organization itself, the member states and the citizenry. It also implies a mutual acknowledge ${ }^{\mathrm{Ir} 9}$ as actors and the rules comprising that relation. Summing up, it means that legitimacy is created within a group process of dialogue on the basis and study of the behaviour of one of the actors. It implies this legitimacy is conditioned by the values, principles and original objectives of the community. Therefore, the social legitimacy of an international organization is consolidated when the states and the citizenry participating within the community addressed around an organization, subjectively assess - in a dialogue process, mutually influenced and understood - the objective elements connecting them to that community.

II3 For a study of empirical cases see: Gutiérrez-Solana, supra n. 6.

II4 Payne and Samhat, supra n. I2.

IIs M. Bukovansky, Legitimacy and power politics (New Jersey, Princeton University Press, 2002).

II6 Frederking, supra n. 24.

ir7 Miyaoka, supra n. I7.

II8 Reus-Smit, supra n. 3I.

II Ruggie, supra n. 27. 
Assuming that legitimacy is generally associated to the level of acceptance and consensus with respect to the rules, laws or organizations in a society ${ }^{120}$, the concept of social legitimacy revisits the process by which an international organization reflects its level of political authority and on the basis of what raises that image. Legitimacy is not only a data nor an objective dimension. It is a subjective perception, a construction made by a group, a social image. It was not about discovering the social identity's process of construction ${ }^{\text {I2I }}$ but through disconnecting from the study of the self concept the proposal was to know the external image of the organization. This way, an IGO external image is defined in relation to the different meanings and social perceptions transmitted by the actors of the social relation it operates.

Analysing the construction of legitimacy as a perception a process of discursive base legitimisation is observed ${ }^{122}$, where the public expressions of the legitimizing actors on certain objective dimensions build the final external image. As mentioned before, the process of creating the social legitimacy image of an IGO means a double analysis of its legitimacy, which means that their activity is analysed both by the member states and by the global civil society. Firstly, the dimensions both actors analyse refer to the behaviour and represent the adjustment between the moral values and the objectives. Secondly, the fulfilling of the principle of legality understood as the right to develop rules and, overall, the respect to the intended procedure. The third dimension the actors analyse in the double analysis of legitimacy is the effectiveness because societies hold political instruments of government in order to meet specific objectives.

It is essential the insistence in defining the social legitimacy as a perception. The results of the dialogue process between actors of a global political community like an international organization, although dealing with more or less material elements, the objective dimensions and their effective fulfilling, are irrelevant to a large extent. Since social legitimacy is a concept associated to the field of ideas and perceptions its consolidation will arise from the positive perception of the actors beyond the material reality. Delegitimizing discourses affect the ultimate perception of an IGO independently of its empirical basis. Thus, frequent speeches are heard pointing at the European Union as a technocratic organization in which the national political actors are nearly marginalized although this does not correspond to the material reality ${ }^{\mathrm{r} 23}$. On the opposite side, there are almost no public discourses about technical international organizations ant this can be the limit to the extension of this notion that it must be proved in the forthcoming analyses.

In conclusion, the notion of social legitimacy is useful because it does not mean a closed proposal of analysis of the international organizations legitimacy but it is a dynamic framework that enable, and this is very important, the classification of the impression of a specific IGO legitimacy. Because legitimacy is a subjective perception of the international organizations and it is not the only resulting

${ }_{220}$ D. Lee y R. Wilkinson, The WTO after Hong Kong (New York, Routledge, 2007), at 206.

I2I A. Wendt, "Collective identity and the International state", 88 (2) American Political Science Review (1994) 384-396, at 385 [doi: $10.2307 / 29447 \mathrm{II}]$

ז22 S. Schneider, F. Nullmeier and A. Hurrelmann, "The communicative dimension" in A. Hurrelman, S. Schneider and J. Steffek, (eds), Legitimacy in an Age of Global Politics (New York, Palgrave, 2007) I26-I55, at I53-I54.

${ }^{123}$ A. Smith, Le gouvernement de l'Union européenne. Une sociologie politique (Paris, LGDG, 2004), at 173. 
public image, the study of this quality should facilitate the access to the weakness and strengths of its public authority. In fact, its double analysis character means the possibility that an organization is assessed with a high level of legitimacy by the states (first possible social perception), and, yet, to achieve an impression of low legitimacy from a civil society point of view (second possible social perception). This comes from the study of perceptions of States and civil society respect to the World Trade Organization (WTO) in the negotiations in the Doha Round ${ }^{124}$. Both images of legitimacy do not have to coincide and they can have different levels, and again images, on the basis of each objective dimension. That is, an actor can have an impression of a globally legitimate IGO (social perception A) but its specific image is based on a general agreement with its moral values (social perception $\mathrm{AI}$ ), a certain critic to the IGO behaviour on the basis of the principle of legality (social perception $\mathrm{A}_{2}$ ), and, finally, a total lack of confidence on the organization effectiveness, delegitimizing that part of the behaviour (social perception $\mathrm{A}_{3}$ ).

For example, this is clear from the states and civil society discourses in relation to the United Nations (UN) during the Iraq war in $2003^{125}$. This way, in the legitimisation process of an organization, the different actors give legitimacy to the IGO or to some of its elements in a different way connecting them to their own previous political images ${ }^{126}$.

The notion of social legitimacy underlines both the fact that it is a perception built on the social interaction of actors and its inconsistency. The impressions of the actors respect to the objective dimensions defining behaviour are based on intersubjective variable meanings, because the actors review their interpretations, their learnt meanings when receiving new information ${ }^{127}$. The frequent perceptions, the social images constantly reflected in discourses built from the IGO behaviour's observation imply essential weakness or strength in the social image of that organization. This repetition of the results can be both regarding different actors and in different successive case studies on the same organization modifying the temporary framework of research. Thus, from a possible perception of social illegitimacy it can be investigated if it corresponds to a failure in the internal structure or failures in the communication skills $\mathrm{s}^{128}$ of the own organization that provoke the arise of blurred images.

${ }_{224}$ Discourse analysis available in: A. Gutiérrez-Solana, supra n. 6, at 171-202.

I25 Ibid., at I25-I52.

${ }_{226}$ T. Diez, M. Jachtenfunchs and S. Jung, supra n. 60.

${ }_{27}$ A. Wendt, Social Theory of International Politics (New York, Cambridge University Press, 1999), at 332.

${ }_{22} 8$ A. Smith, "Conclusion. Politics in the European Union" in A. Smith (ed), Politics and the European Commission (London, Routledge, 2004), at. 203-204. 